\title{
Lactobacillus casei-fermented milk as an inhibitor on selected foodborne pathogens
}

\author{
BAHAR ONARAN ACAR ${ }^{1}$, NAZLI KANCA², RABIA ALBAYRAK DELİALIOĞLU³
}

\begin{abstract}
${ }^{1}$ Department of Food Hygiene and Technology, Faculty of Veterinary Medicine, Ankara University, 06110, Ankara, Turkey
${ }^{2}$ Department of Dairy Technology, Faculty of Agriculture, Ankara University, 06110, Ankara, Turkey

${ }^{3}$ Faculty of Agriculture Biometry and Genetics Unit, Ankara University, 06110, Ankara, Turkey
\end{abstract}

\section{Onaran Acar B., Kanca N., Albayrak Delialioğlu R. Lactobacillus casei-fermented milk as an inhibitor on selected foodborne pathogens}

\section{Summary}

The aim of this study was to reduce the growth of vanB resistant Enterococcus faecium, vanA resistant Enterococcus faecalis, Staphylococcus aureus ATCC 43300 and methicillin-resistant Staphylococcus aureusMRSA ATCC 25923, which are foodborne pathogens that cause the death of a significant number of people every year, by the presence of Lactobacillus casei. For this purpose, the development of pathogens (10 ${ }^{4}$ and $\left.10^{6} \mathrm{log} \mathrm{cfu} / \mathrm{ml}\right)$ in milk fermented with $\mathrm{L}$. casei $\left(10^{6} \log \mathrm{cfu} / \mathrm{ml}\right)$ was followed under in vitro conditions for 72 hours. Moreover, the generation times of each pathogen and the lactic acid content of fermented milk were determined. It was determined that the development of all pathogens could be suppressed by the presence of $L$. case $i$ considering the change in generation times and the number of pathogens during the 72 hour fermentation period. This effect was greater in samples containing $10^{4} \log \mathrm{cfu} / \mathrm{ml}$ pathogen compared to samples containing $10^{6} \log \mathrm{cfu} / \mathrm{ml}$.

Keywords: Enterococcus faecium, Enterococcus faecalis, methicillin, Staphylococcus aureus, van $\mathrm{A}$, vanB

Antibiotic resistance, which emerges in pathogenic microorganisms, is an important public health threat in the world, and occurs as a result of the widespread and often misuse of antibiotics. In many cases, due to the resistant bacteria infections may require prolonged hospital stays, this provides additional follow-up visits to healthcare providers and the use of possible treatments can be more costly and potentially more toxic (Centers for Disease Control and Prevention-CDC, available online at https://www.cdc.gov/drugresistance/index. $\mathrm{html}$, accessed June 7, 2021). On the other hand, broadspectrum antibiotics can have devastating effects on the microbiota of individuals. Therefore, antibiotic treatment may cause damage to the microbiota, compromise immunity, and provoke infections and metabolic disorders. According to the World Health Organization (WHO), approximately 700,000 people die every year due to antimicrobial-resistant bacteria. It is predicted that this number will reach 10 million by 2050 if no action is taken, and will overshadow even the number of cancer-related deaths (available online at https:// www.who.int/activities/estimating-the-burden-offoodborne-diseases, accessed June 7, 2021). Another dangerous situation is the fact that animals also carry a large number of zoonotic and commensal bacteria, including antibiotic-resistant bacteria in their gut, and these bacteria can be transmitted to humans through foods (CDC, available online at https://www.cdc.gov/ drugresistance/index.html, accessed June 7, 2021).

Enterococci and staphylococci have an important place among foodborne pathogens. Enterococci are ubiquitous microorganisms and have a predominant habitat in the gastrointestinal tract of humans and animals (35). Due to their resistance to high temperatures and adverse environmental conditions, they can colonize in many media and are considered as an indicator of food hygiene criteria in foods (13). Enterococci can be found widely in foods of animal origin, especially dairy and meat products $(6,10)$. In the genus staphylococci, Staphylococcus aureus is the most common bacteria among foodborne pathogens (24). It has the ability to grow in foods with tolerance to different environmental conditions, to have various virulence factors, to develop multiple resistance to antibiotics and disinfectants, and to form biofilms on surfaces/ tools and equipment $(14,25)$. Moreover, $S$. aureus can produce a significant amount of heat-resistant enterotoxins when it reaches levels of $10^{6} \mathrm{cfu} / \mathrm{g}$ or higher in foods and is responsible for staphylococcal food intoxications (26). Therefore, preventing $S$. aureus from 
reaching $6 \log \mathrm{cfu} / \mathrm{g}$ in foods is of great importance in terms of food safety.

According to CDC, 2 out of 5 pathogens caused by nosocomial infections in the US are vancomycinresistant Enterococcus (VRE) and Methicillin-resistant $S$. aureus (MRSA). It has been reported that 54,500 VRE and 323,700 MRSA infections occur annually in hospitalized patients in the USA, and these infections cause approximately 5,400 and 10,600 deaths, respectively (CDC, available online at https://www. cdc.gov/drugresistance/biggest-threats.html\#van, accessed June 7, 2021). Moreover, van A and $\operatorname{van} \mathrm{B}$ resistance genes are known to be the most common resistance genes implicated in VRE infections (16). The presence of VRE and MRSA infections in hospitalized patients indicates that these pathogens are taken through foods unless the infected persons were previously hospitalized and used antibiotics. These pathogens can contaminate foods through environmental sources such as sewage treatment systems, livestock feces, raw milk and meat. Milk contaminated by environmental factors due to inadequate technical and hygienic conditions in dairy farms is an important source for both VRE and MRSA, as well as a source for antibiotic resistance (12).

Probiotics are live microorganisms which are considered as non-pathogenic flora and provide human health benefits. Probiotic bacteria reduce the colonization of pathogens in the intestine and thus reduce the susceptibility to infection (23). The health effects of probiotics include balancing colon microbiota, protecting intestinal microbiota, antimicrobial effect against foodborne pathogens, preventing gastrointestinal system disorders, reducing serum cholesterol, and enhancing the nutritional value of products $(15,30$, 33). Lactic acid bacteria (LAB) are the most commonly used probiotics and are especially used in fermented milk products. It was stated that LAB-containing fermented milk showed various health benefits and protective effects against diseases $(22,34)$. In addition, LAB has antimicrobial properties against many intestinal and foodborne pathogens by showing the ability to inhibit the adhesion, toxin production and/or invasion of those microorganisms (29). The reason for their ability to inhibit pathogenic microorganisms can be attributed to the organic acids causing a decrease in $\mathrm{pH}$ and/or the hydrogen peroxide formed during their growth. On the other hand, LAB has been reported to compete with pathogens for adhesion sites or nutrients (3). LAB can also produce antibacterial peptides called bacteriocins, thus they can provide effective properties against pathogens. One of the most commonly used LAB bacteria is Lactobacillus casei and it has been shown in previous studies that this probiotic has preventive effects against antibiotic-related and Clostridium difficile-associated diarrhea (20).

The aim of this study was to determine the reducing effect of the L. casei on vanB resistant Enterococcus faecium $\mathrm{FC} 21$ and vanA resistant Enterococcus faecalis EC32 isolates, Staphylococcus aureus ATCC 43300 and methicillin-resistant Staphylococcus aureusMRSA ATCC 25923 in fermented milk during $72 \mathrm{~h}$.

\section{Material and methods}

Bacterial strains. Commercial Lactobacillus casei strain (Lactoferm L Series, LC) were obtained from Biochem (Rome, Italy). vanB resistant E. faecium $\mathrm{FC} 21$ isolate, vanA resistant $E$. faecalis $\mathrm{EC} 32$ isolate and $S$. aureus ATCC 43300 were obtained from the Veterinary Faculty of Ankara University. MRSA ATCC 25923 was obtained from the Veterinary Faculty of Burdur Mehmet Akif Ersoy University. Enterococci and staphylococci strains were enriched in Brain Heart Infusion Broth (BHI; Oxoid CM1135) and Lactobacillus casei was activated in sterile reconstituted skimmed milk $(10 \% \mathrm{w} / \mathrm{w})$ by two sequential incubations at $37^{\circ} \mathrm{C}$ for $24 \mathrm{~h}$. Skim milk powder (Bakkalbasioglu Sut Urunleri San. ve Tic. A.S., Nigde, Turkey) was reconstituted to $10 \%(\mathrm{w} / \mathrm{w})$ and sterilized at $121^{\circ} \mathrm{C}$ for $2 \mathrm{~min}$.

Enterococci and staphylococci strains were diluted with Buffered Peptone Water (BPW, Oxoid CM0509) to achieve an inoculum containing $10^{6}$ and $10^{9} \mathrm{cfu} / \mathrm{ml}$. When $1 \mathrm{ml}$ of each strain containing $10^{6}$ and $10^{9} \mathrm{cfu} / \mathrm{ml}$ was added to the $250 \mathrm{ml}$ of sterile reconstituted milk, the final product contained $10^{4}$ and $10^{6} \mathrm{cfu} / \mathrm{ml}$ bacteria, respectively. Experimental contamination of $250 \mathrm{ml}$ of milk samples was carried out into sixteen groups in duplicate as specified in Table 1 .

Microbial analysis. After the contamination of sterile milk, $10 \mathrm{ml}$ of milk samples were taken at $0,4,8,24,48$ and $72 \mathrm{~h}$ to determine the bacterial counts during fermentation. Serial dilutions were prepared in $9 \mathrm{ml}$ of Ringer solution (Merck 115525) and microbial analyses were carried

Tab. 1. Experimental contamination of sterile reconstituted milk samples

\begin{tabular}{|c|c|c|}
\hline Group & $\begin{array}{l}\text { Pathogen - concentration } \\
\text { (cfu/ml) }\end{array}$ & $\begin{array}{l}\text { L. casei concentration } \\
\text { (cfu/ml) }\end{array}$ \\
\hline \multirow{4}{*}{ A } & E. faecium $-10^{6}$ & - \\
\hline & E. faecium $-10^{6}$ & $10^{6}$ \\
\hline & E. faecium $-10^{4}$ & - \\
\hline & E. faecium $-10^{4}$ & $10^{6}$ \\
\hline \multirow{4}{*}{ B } & E. faecalis $-10^{6}$ & - \\
\hline & E. faecalis $-10^{6}$ & $10^{6}$ \\
\hline & E. faecalis $-10^{4}$ & - \\
\hline & E. faecalis $-10^{4}$ & $10^{6}$ \\
\hline \multirow{4}{*}{ C } & S. aureus ATCC $43300-10^{6}$ & - \\
\hline & S. aureus ATCC $43300-10^{6}$ & $10^{6}$ \\
\hline & S. aureus ATCC $43300-10^{4}$ & - \\
\hline & S. aureus ATCC $43300-10^{4}$ & $10^{6}$ \\
\hline \multirow{4}{*}{ D } & MRSA ATCC $25923-10^{6}$ & - \\
\hline & MRSA ATCC $25923-10^{6}$ & $10^{6}$ \\
\hline & MRSA ATCC $25923-10^{4}$ & - \\
\hline & MRSA ATCC $25923-10^{4}$ & $10^{6}$ \\
\hline
\end{tabular}

Explanation: MRSA - Methicillin-Resistant Staphylococcus aureus 
out using the classic culture method on selective media in duplicate. De Man Ragosa Sharpe Agar (MRS, Merck 110660) was used for the enumeration of $L$. case $i$ and the plates were incubated at $37^{\circ} \mathrm{C}$ for $48 \mathrm{~h}$. Enterococci and staphylococci were pour-plated on Slanantz Bartley Agar (SB, Oxoid CM0377) and Baird Parker Agar Base (BP, Oxoid CM0275), respectively. Aerobic incubation conditions were applied for both media at $37^{\circ} \mathrm{C}$ for 24 to $48 \mathrm{~h}$. The colonies were counted after the incubation period and the results were stated as $\log \mathrm{cfu} / \mathrm{ml}$.

Generation time. Generation time was calculated according to Millette et al. (19) using the formula below and the results were expressed as min.

$$
\begin{gathered}
k=\left[\left(\log N_{\mathrm{t}}-\log N_{0}\right) / 0.301 \times t\right] \\
\mathrm{g}=1 / k
\end{gathered}
$$

where $\mathrm{g}$ is the generation time $(\mathrm{h}), \mathrm{k}$ is the division rate $\left(\mathrm{h}^{-1}\right), t$ is 8 (the $8^{\text {th }} \mathrm{h}$ of fermentation). $\log N_{\mathrm{t}}$ and $N_{0}$ are the microbial counts $(\mathrm{cfu} / \mathrm{ml})$ after $8 \mathrm{~h}$ and $4 \mathrm{~h}$ of incubation respectively.

Titratable acidity. Milk samples $(10 \mathrm{~g})$ were titrated with $0.1 \mathrm{~N} \mathrm{NaOH}$ in the existence of phenolphthalein and lactic acid (\%) content of the samples were calculated using the volume and the normality of titrant used. Titratable acidity analyses were carried out in $0,4,8,24,48$ and $72 \mathrm{~h}$ of incubation in duplicate.

Statistical analysis. The data obtained for the microbial counts (pathogens and L. casei) and lactic acid contents were evaluated using repeated measurement analysis of variance technique in a factorial design. For pathogen counts and lactic acid contents, the time factor had six levels $(0,4,8$, 24, 48 and $72 \mathrm{~h}$ ), the pathogen factor had four levels (A, $\mathrm{B}, \mathrm{C}, \mathrm{D})$, the pathogen concentration factor had two levels $\left(10^{4}, 10^{6} \mathrm{cfu} / \mathrm{ml}\right)$ and the probiotic factor had two levels (L. casei-free, containing L. casei). L. casei counts were also analyzed using repeated measurement analysis of variance technique in a factorial design with the same factors except for the probiotic factor. In experiments, repeated measurements were performed at the levels of the time factor. The generation times were evaluated with the factorial analysis of variance in randomized plot design. In this experiment, unlike other variables, only pathogen, pathogen concentration and probiotic factors were present. The data obtained for the generation time, lactic acid content, L. casei and pathogen counts were evaluated using IBM SPSS Statistics 22 package program and Duncan multiple comparison test was used to determine the differentiate groups.

\section{Results and discussion}

According to the findings, it was determined that the pathogen counts were lower in all of the $L$. case $i$ added samples compared to the samples without L. casei addition $(\mathrm{p}<0.05)$ (Fig. 1). As expected, a higher inhibition rate was achieved in all of the samples to which $10^{4} \mathrm{cfu} / \mathrm{ml}$ pathogen was added compared to those to which $10^{6} \mathrm{cfu} / \mathrm{ml}$ was added. While it was determined that the effect of $L$. casei on pathogen development was seen from the $8^{\text {th }}$ hour of fermentation in the samples with $10^{4} \mathrm{cfu} / \mathrm{ml}$ pathogens, this effect could only be seen after the $24^{\text {th }}$ hour in the samples with $10^{6} \mathrm{cfu} / \mathrm{ml}$ pathogens. Moreover, it was determined that the generation time was prolonged for all pathogens in $L$. casei samples and this increase was higher in samples containing $10^{4} \mathrm{cfu} / \mathrm{ml}$ pathogens (Tab. 2). While the generation time increased between 56.51 and $204.80 \mathrm{~min}$ with the addition of $L$. casei in the samples with $10^{6} \mathrm{cfu} / \mathrm{ml}$ pathogens, it was determined that this increase was between 60.16 and $351.30 \mathrm{~min}$ in the samples with $10^{4} \mathrm{cfu} / \mathrm{ml}$ pathogens.

The ability of lactic acid bacteria to suppress the growth of pathogens is due to their antagonistic effect (8). These bacteria have the ability to prevent the

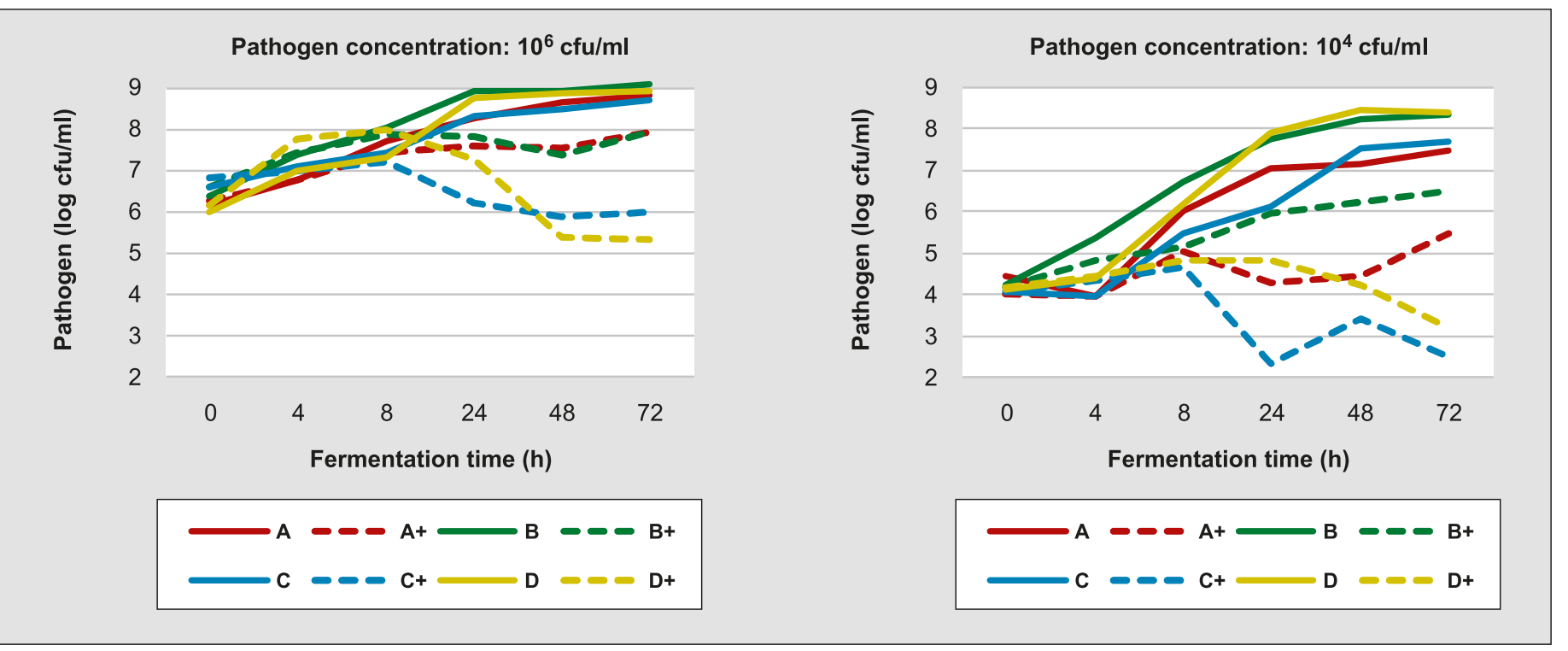

Fig. 1. Pathogen counts of $L$. casei-free and $L$. casei added samples with different concentrations of pathogens during $72 \mathrm{~h}$ of fermentation $(n=2)$

Explanations: A, A+-van B resistant Enterococcus faecium $\mathrm{FC} 21$ isolate; B, B+-vanA resistant Enterococcus faecalis EC32 isolate; C, C+-Staphylococcus aureus ATCC 43300; D, D+- methicillin-resistant Staphylococcus aureus-MRSA ATCC 25923; A, B, C, D - L. casei-free samples; $\mathrm{A}+, \mathrm{B}+, \mathrm{C}+, \mathrm{D}+-$ L. casei added samples 
Tab. 2. Generation times of $L$. casei-free and $L$. case $i$ added samples with different concentrations of pathogens $(n=2)$

\begin{tabular}{|c|c|c|c|c|c|}
\hline $\begin{array}{c}\text { Pathogen concentration } \\
\text { (cfu/ml) }\end{array}$ & L. casei & \multicolumn{4}{|c|}{ Pathogen } \\
\hline $10^{6}$ & - & $152.93 \pm 2.430^{\mathrm{AaC}}$ & $231.90 \pm 13.000^{\mathrm{BaB}}$ & $468.00 \pm 30.200^{\mathrm{BaA}}$ & $453.30 \pm 28.300^{\mathrm{BaA}}$ \\
& + & $209.44 \pm 3.040^{\mathrm{AaC}}$ & $343.80 \pm 36.400^{\mathrm{AbB}}$ & $615.10 \pm 13.100^{\mathrm{AaA}}$ & $658.10 \pm 29.900^{\mathrm{AaA}}$ \\
$10^{4}$ & - & $70.14 \pm 0.340^{\mathrm{AbA}}$ & $110.30 \pm 0.842^{\mathrm{BbA}}$ & $96.47 \pm 6.730^{\mathrm{BbA}}$ & $80.44 \pm 8.200^{\mathrm{BbA}}$ \\
& + & $130.30 \pm 12.800^{\mathrm{AbC}}$ & $461.60 \pm 36.600^{\mathrm{AaA}}$ & $426.40 \pm 25.100^{\mathrm{AbA}}$ & $352.60 \pm 8.600^{\mathrm{AbB}}$ \\
\hline
\end{tabular}

Explanations: Different uppercase letters denote statistical differences between the samples with and without $L$. casei addition $(\mathrm{p}<0.05)$. Different lowercase letters denote statistical differences between the samples with different concentrations $\left(10^{4}\right.$ and $10^{6}$ $\mathrm{cfu} / \mathrm{ml})$ of pathogens $(\mathrm{p}<0.05)$. Different italic uppercase letters denote statistical differences between the samples with different (A, B , C , D) pathogens ( $\mathrm{p}<0.05)$. A - vanB resistant Enterococcus faecium FC21 isolate; B - vanA resistant Enterococcus faecalis EC32 isolate; C - Staphylococcus aureus ATCC 43300; D - methicillin-resistant Staphylococcus aureus-MRSA ATCC 25923; +- L. casei added samples, --L. casei-free samples

colonization of other microorganisms using the nutrients necessary for their growth in the environment. Lactic acid bacteria can also significantly inhibit the growth of pathogens by producing some important metabolites (31).

Lactic and acetic acid, the main metabolites produced by lactic acid bacteria, penetrate the microbial cell and interfere with basic cell functions, lowering the intracellular $\mathrm{pH}$ as well as the ambient $\mathrm{pH}$, thereby slowing the metabolic activity of pathogens (21). As it is seen in Fig. 2, while there was no difference between the titration acidity values of the samples at the beginning of fermentation $(p>0.05)$, as the fermentation period progressed, the amount of lactic acid increased with the increase in the number of microorganisms capable of producing lactic acid $(\mathrm{p}<0.05)$.

Another reason for the suppression of pathogen growth with the addition of $L$. case $i$ is that benzoic acid, which is known to be found especially in fermented milk as a result of the metabolic activities of some lactic acid bacteria such as $L$. casei, has an inhibitory effect against pathogens (37). L. casei also has the ability to produce pyroglutamic acid, which is also found in fruits and vegetables, and this metabolite has been reported to have a greater antimicrobial effect on pathogens than lactic acid (36). Moreover, the carbon dioxide produced by $L$. case $i$ affects the growth rate and competitiveness of bacteria by reducing the redox potential $\left(\mathrm{E}_{\mathrm{h}}\right)$, which significantly affects $\mathrm{pH}$, temperature and water activity parameters. It has been reported that this situation suppresses the growth of bacteria such as enterococci and staphylococci $(17,21)$. It has also been stated that diacetyl and acetaldehyde, which are known as end products of pyruvate and carbohydrate metabolism, respectively, have inhibitory effects on pathogenic microorganisms $(18,21)$.

Another important antimicrobial effect of lactobacilli is their role in blocking glycolysis. It has been reported that glucose transfer, hexokinase activity and glyceraldehyde-3-phosphate dehydrogenase activity are inhibited due to the oxidation of sulfhydryl groups (5).

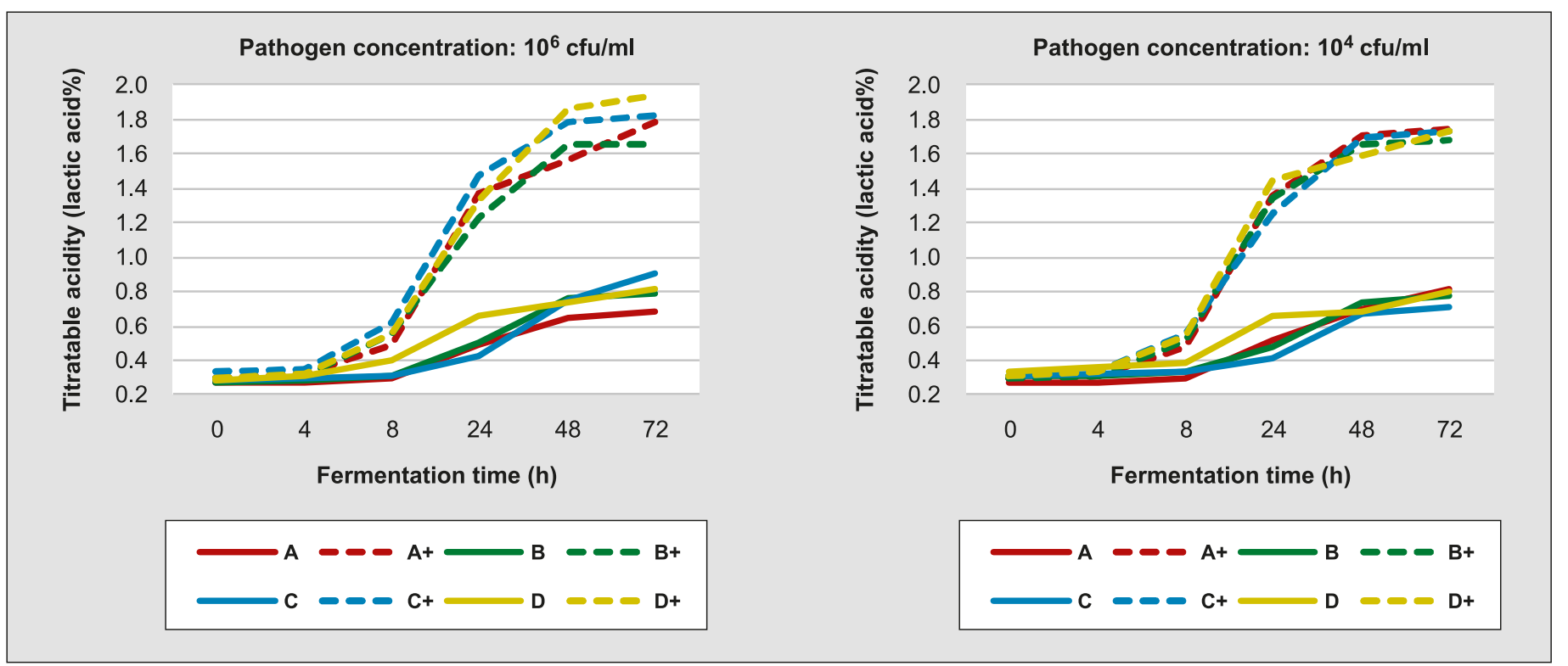

Fig. 2. Titratable acidity (lactic acid\%) values of $L$. casei-free and $L$. casei added samples with different concentrations of pathogens during $72 \mathrm{~h}$ of fermentation $(\mathrm{n}=\mathbf{2})$

Explanations: as in Fig. 1. 
Tab. 3. $L$. casei counts of the samples with different concentrations of pathogens during $72 \mathrm{~h} \mathrm{of} \mathrm{fermentation}(\log \mathrm{cfu} / \mathrm{ml})(\mathrm{n}=2)$

\begin{tabular}{|c|c|c|c|c|c|}
\hline \multirow{2}{*}{$\begin{array}{l}\text { Pathogen concentration } \\
\text { (cfu/ml) }\end{array}$} & \multirow{2}{*}{$\begin{array}{l}\text { Fermentation time } \\
\text { (h) }\end{array}$} & \multicolumn{4}{|c|}{ Pathogen } \\
\hline & & A & B & C & D \\
\hline \multirow{6}{*}{$10^{6}$} & 0 & $6.55 \pm 0.190^{\mathrm{BaA}}$ & $6.31 \pm 0.010^{\mathrm{DaA}}$ & $6.38 \pm 0.080^{\text {ЕаА }}$ & $6.39 \pm 0.015^{\mathrm{Da} A}$ \\
\hline & 4 & $6.47 \pm 0.235^{\mathrm{Ba} B}$ & $7.10 \pm 0.450^{\mathrm{CaA}}$ & $6.68 \pm 0.025^{\text {DЕа } A B}$ & $6.74 \pm 0.060^{\mathrm{Da} A B}$ \\
\hline & 8 & $7.56 \pm 0.345^{\mathrm{Ab} A}$ & $7.97 \pm 0.370^{\mathrm{BaA}}$ & $7.73 \pm 0.105^{\mathrm{Cb} A}$ & $8.03 \pm 0.040^{\mathrm{BaA}}$ \\
\hline & 24 & $7.78 \pm 0.220^{\mathrm{Aa} B}$ & $8.72 \pm 0.010^{\mathrm{AaA}}$ & $8.94 \pm 0.050^{\mathrm{AaA}}$ & $8.62 \pm 0.210^{\mathrm{Aa} A}$ \\
\hline & 48 & $7.72 \pm 0.285^{A b C}$ & $8.77 \pm 0.300^{\mathrm{AaA}}$ & $8.20 \pm 0.030^{\mathrm{B} a B C}$ & $8.35 \pm 0.100^{A B a A B}$ \\
\hline & 72 & $7.51 \pm 0.205^{А а A B}$ & $7.60 \pm 0.245^{\mathrm{BaA}}$ & $7.01 \pm 0.105^{\mathrm{Da} B}$ & $7.19 \pm 0.190^{\mathrm{C} \triangleright \mathrm{A} B}$ \\
\hline \multirow{6}{*}{$10^{4}$} & 0 & $6.32 \pm 0.065^{\mathrm{Ca} A}$ & $6.33 \pm 0.140^{\mathrm{CaA}}$ & $6.24 \pm 0.040^{\mathrm{CaA}}$ & $6.68 \pm 0.075^{\mathrm{BaA}}$ \\
\hline & 4 & $6.54 \pm 0.065^{\mathrm{CaA}}$ & $6.55 \pm 0.205^{\mathrm{Cb} A}$ & $6.58 \pm 0.025^{\mathrm{CaA}}$ & $6.86 \pm 0.040^{\mathrm{BaA}}$ \\
\hline & 8 & $8.09 \pm 0.305^{\mathrm{AaA}}$ & $8.20 \pm 0.130^{\mathrm{AaA}}$ & $8.46 \pm 0.040^{\mathrm{AaA}}$ & $8.42 \pm 0.020^{\mathrm{Aa} A}$ \\
\hline & 24 & $8.13 \pm 0.125^{\text {Аа } A}$ & $8.50 \pm 0.250^{\mathrm{AaA}}$ & $8.28 \pm 0.030^{\mathrm{AbA}}$ & $8.40 \pm 0.075^{\mathrm{Aa} A}$ \\
\hline & 48 & $8.25 \pm 0.250^{\mathrm{Aa} A}$ & $8.14 \pm 0.065^{\mathrm{Ab} A B}$ & $7.72 \pm 0.280^{\mathrm{Ba}}$ & $8.45 \pm 0.105^{\mathrm{AaA}}$ \\
\hline & 72 & $7.34 \pm 0.105^{\text {Вав }}$ & $7.53 \pm 0.075^{\mathrm{BaB}}$ & $7.39 \pm 0.085^{\text {Вав }}$ & $8.07 \pm 0.145^{\text {Аа } A}$ \\
\hline
\end{tabular}

Explanations: Different uppercase letters denote statistical differences between the samples in different times of the fermentation period $(\mathrm{p}<0.05)$. Different lowercase letters denote statistical differences between the samples with different concentrations $\left(10^{4}\right.$ and $\left.10^{6} \mathrm{cfu} / \mathrm{ml}\right)$ of pathogens $(\mathrm{p}<0.05)$. Different italic uppercase letters denote statistical differences between the samples with different (A, B, C, D) pathogens ( $\mathrm{p}<0.05)$. A - vanB resistant Enterococcus faecium $\mathrm{FC} 21$ isolate; B - vanA resistant Enterococcus faecalis EC32 isolate; C - Staphylococcus aureus ATCC 43300; D - methicillin-resistant Staphylococcus aureus-MRSAATCC 25923

As it is seen in Fig. 1, when the pathogen counts at the beginning of fermentation and $72^{\text {nd }} \mathrm{h}$ were compared it was determined that the pathogen counts of $L$. casei containing C and D samples were lower than at the $0^{\text {th }}$ hour. Although lower pathogen counts were detected in samples A and B than those without $L$. case $i$ addition, the number of pathogens at the end of fermentation was higher than at the beginning. It was determined that this situation was not affected by the amount of added pathogen $(\mathrm{p}>0.05)$. Therefore, considering the pathogens examined in the study it is possible to say that the addition of $L$. case $i$ was more effective on $S$. aureus ATCC 43300 and MRSA ATCC 25923 pathogens.

One of the most important reasons for this situation can be indicated as the fact that $S$. aureus is more sensitive to bacteriocins and hydrogen peroxide that $L$. case $i$ is capable of producing $(27,32)$. Bacteriocins are polypeptides that are ribosomally synthesized by bacteria and have a bactericidal or bacteriostatic effect on competitive bacteria. These generally cause cell death by inhibiting cell wall biosynthesis or by damaging the membrane through forming pores (9). Schillinger et al. (27) reported that bacteriocins produced by $L$. casei are effective on staphylococci. Hydrogen peroxide, on the other hand, has a strong oxidizing effect on bacterial cells and cell proteins and sulfhydryl groups in membrane lipids (7). It was stated that $S$. aureus is highly sensitive to hydrogen peroxide and can be effectively inhibited in the presence of hydrogen peroxide (38). Furthermore, Gaca and Lemos (11) reported that enterococci has the ability to develop resistance to hydrogen peroxide.

Another important reason why staphylococci can be inhibited at a higher rate than enterococci is thought to be related to acidity. It was stated that the growth of $S$. aureus slows down at high acidity (1), while enterococci can survive in a wide $\mathrm{pH}$ range and are highly resistant to acidic environments (11). Additionally, L. casei, due to its ability to produce carbon dioxide (17), contributes to the gradual decrease of oxygen and the formation of an anaerobic environment (21). Therefore, it is thought that this situation is also effective in suppressing the growth of $S$. aureus, which is known to be aerobic, more than E. faecium and E. faecalis growing in anaerobic conditions.

As it is seen in Table 3, the amount of L. casei in the samples showed an increasing trend during the fermentation period but decreased at the end of the fermentation. This change in the amount of $L$. casei is thought to be related to the increase in the amount of lactic acid accumulated in the environment as the fermentation period progresses. According to Capela et al. (4), lactic acid bacteria are affected by changing environmental conditions and get stressed, thus probiotic viability may decrease. As a matter of fact, Shah (28) reported that the growth of $L$. casei was suppressed with the effect of developing acidity in acidic fermented milk products such as yogurt.

In conclusion, $L$. casei showed an inhibitory effect on all pathogens (vanB resistant E. faecium, vanA resistant $E$. faecalis, $S$. aureus ATCC 43300, methicillin-resistant $S$. aureus-MRSA ATCC 25923) and prolonged the generation time in the fermented milk samples. L. case $i$ was more efficient on $S$. aureus ATCC 43300 and MRSA ATCC 25923 compared to the enterococci strains. Thus the results showed that the growth of these bacteria, which is one of the most common foodborne pathogens in the world, can be suppressed under in vitro conditions by the presence 
of $L$. casei, and more importantly, it can prevent the spread of antibiotic resistance. In addition, it is thought that the results obtained from this study may guide future in vivo studies on the use of $L$. casei-fermented milk in the prevention of antibiotic resistance.

\section{References}

1. Al-Delaimy K. S., Hamamdeh Y. M.: Inhibition of Staphylococcus aureus by lactic acid bacteria and/or Bifidobacterium lactis during milk fermentation and storage. J. Microbiol. Biotechnol. Food Sci. 2013, 2, 2406-2419.

2. Andersson D. I., Hughes D.: Persistence of antibiotic resistance in bacterial populations. FEMS Microbiol. Rev. 2011, 35, 901-911.

3. Beausoleil M., Fortier N., Guénette S., L'Ecuyer A., Savoie M., Franco M. Lachaine J., Weiss K.: Effect of a fermented milk combining Lactobacillus acidophilus C11285 and Lactobacillus casei in the prevention of antibioticassociated diarrhea: a randomized, double-blind, placebo-controlled trial. Can. J. Gastroenterol. 2007, 21, 732-736.

4. Capela P., Hay T. K. C., Shah N. P.: Effect of cryoprotectants, prebiotics and microencapsulation on survival of probiotic organisms in yoghurt and freezedried yoghurt. Food Res. Int. 2006, 39, 203-211.

5. Carlsson J., Iwami Y., Yamada T.: Hydrogen peroxide excretion by oral streptococci and effect of lactoperoxidase thiocyanate-hydrogen peroxide. Infect. Immun. 1983, 40, 70-80.

6. Chajęcka-Wierzchowska W., Zadernowska A., Garcia-Solache M.: Ready-toeat dairy products as a source of multidrug-resistant Enterococcus strains: Phenotypic and genotypic characteristics. J. Dairy Sci. 2020, 103, 4068-4077.

7. Dicks L. M. T., Botes M.: Probiotic lactic acid bacteria in the gastro-intestina tract: health benefits, safety and mode of action. Benef. Microbes 2010,1,11-29.

8. Espeche M. C., Pellegrino M., Frola I., Larriestra A., Bogni C., Nader-Macías $M$. F.: Lactic acid bacteria from raw milk as potentially beneficial strains to prevent bovine mastitis. Anaerobe 2012, 18, 103-109.

9. Essayas A., Pandit S., Taneja P.: Anti-microbial activity of potential probiotic lactic acid bacteria against Methicillin-Resistant Staphylococcus aureus (MRSA). bioRxiv 2020, doi: 10.1101/2020.03.08.982512.

10. Fracalanzza S. A. P., Scheidegger E. M. D., Santos P. F. D., Leite P. C., Teixeira L. M.: Antimicrobial resistance profiles of enterococci isolated from poultry meat and pasteurized milk in Rio de Janeiro, Brazil. Mem. Inst. Oswaldo Cruz 2007, 102, 853-859.

11. Gaca A. O., Lemos J. A.: Adaptation to adversity: the intermingling of stress tolerance and pathogenesis in enterococci. Microbiol. Mol. Biol. Rev. 2019, 83, e00008-19.

12. Garcia S. N., Osburn B. I., Cullor J. S.: A one health perspective on dairy production and dairy food safety. One Health 2019, 7, 100086

13. Giraffa G.: Enterococci from foods. FEMS Microbiol. Rev. 2002, 26, 163-171.

14. Gutiérrez D., Delgado S., Vázquez-Sánchez D., Martínez B., Cabo M. L. Rodríguez A., Herrera J. J., García P.: Incidence of Staphylococcus aureus and analysis of associated bacterial communities on food industry surfaces. Appl. Environ. Microbiol. 2012, 78, 8547-8554.

15. Hlivak P., Odraska J., Ferencik M., Ebringer L., Jahnova E., Mikes Z.: One-year application of probiotic strain Enterococcus faecium M-74 decreases serum cholesterol levels. Bratisl. Lek. Listy 2005, 106, 67-72.

16. Hoek A. H. V., Mevius D., Guerra B., Mullany P., Roberts A. P., Aarts H. J.: Acquired antibiotic resistance genes: an overview. Front. Microbiol. 2011, 2, 203.

17. Holzapfel W. H., Geisen R., Schillinger $U$.: Biological preservation of foods with reference to protective cultures, bacteriocins and food-grade enzymes. Int. J. Food Microbiol. 1995, 24, 343-362.

18. Lanciotti R., Patrignani F., Bagnolini F., Guerzoni M. E., Gardini F.: Evaluation of diacetyl antimicrobial activity against Escherichia coli, Listeria monocytogenes and Staphylococcus aureus. Food Microbiol. 2003, 20, 537-543.

19. Millette M., Luquet F. M., Lacroix M.: In vitro growth control of selected pathogens by Lactobacillus acidophilus- and Lactobacillus casei-fermented milk. Lett. Appl. Microbiol. 2007, 44, 314-319.

20. Naaber P., Smidt I., Štšepetova J., Brilene T., Annuk H., Mikelsaar M.: Inhibition of Clostridium difficile strains by intestinal Lactobacillus species. J. Med. Microbiol. 2004, 53, 551-554.

21. Naidu A. S., Bidlack W. R., Clemens R. A.: Probiotic spectra of lactic acid bacteria (LAB). Crit. Rev. Food Sci. Nutr. 1999, 39, 13-126.

22. Panebianco F., Giarratana F., Caridi A., Sidari R., De Bruno A., Giuffrida A.: Lactic acid bacteria isolated from traditional Italian dairy products: activity against Listeria monocytogenes and modelling of microbial competition in soft cheese. LWT 2021, 137, 110446.

23. Piewngam P., Zheng Y., Nguyen T. H., Dickey S. W., Joo H. S., Villaruz A. E., Glose K. A., Fisher E. L., Hunt R. L., Li B., Chiou J., Pharkjaksu S., Khongthong S., Cheung G. Y. C., Kiratisin P., Otto M.: Pathogen elimination by probiotic Bacillus via signalling interference. Nature 2018, 562, 532-537.
24. Plata K., Rosato A. E., Wegrzyn G.: Staphylococcus aureus as an infectious agent: overview of biochemistry and molecular genetics of its pathogenicity. Acta Biochim. Pol. 2009, 56, 597-612.

25. Raggi C., Filippini P., Monaco M., Pantosti A., Creti R., Baldassarri L.: Methicillin resistance, biofilm formation and resistance to benzalkonium chloride in Staphylococcus aureus clinical isolates. Clin. Microbial. 2013, 2, 1000121.

26. Schelin J., Wallin-Carlquist N., Thorup Cohn M., Lindqvist R., Barker G. C. The formation of Staphylococcus aureus enterotoxin in food environments and advances in risk assessment. Virulence 2011, 2, 580-592.

27. Schillinger U., Geisen R., Holzapfel W. H.: Potential of antagonistic microorganisms and bacteriocins for the biological preservation of foods. Trends Food Sci. Technol. 1996, 7, 158-164.

28. Shah N. P.: Probiotic bacteria: selective enumeration and survival in dairy foods J. Dairy Sci. 2000, 83, 894-907.

29. Shao X., Xu B., Chen C., Li P., Luo H.: The function and mechanism of lactic acid bacteria in the reduction of toxic substances in food: a review. Crit. Rev. Food Sci. Nutr. 2021, 1-14.

30. Sharma C., Singh B. P., Thakur N., Gulati S., Gupta S., Mishra S. K., Panwar H.: Antibacterial effects of Lactobacillus isolates of curd and human milk origin against food-borne and human pathogens. 3 Biotech. 2017, 7, 31.

31. Stiles M. E., Holzapfel W. H.: Lactic acid bacteria of foods and their current taxonomy. Int. J. Food Microbiol. 1997, 36, 1-29.

32. Stoyanova L. G., Ustyugova E. A., Netrusov A. I.: Antibacterial metabolites of lactic acid bacteria: their diversity and properties. Appl. Biochem. Microbiol. 2012, 48, 229-243.

33. Wan M. L. Y., Forsythe S. J., El-Nezami H.: Probiotics interaction with foodborne pathogens: a potential alternative to antibiotics and future challenges. Crit. Rev. Food Sci. Nutr. 2019, 59, 3320-3333.

34. Wang X., Wang W., Lv H., Zhang H., Liu Y., Zhang M., Wang Y., Tan Z.: Probiotic potential and wide-spectrum antimicrobial activity of lactic acid bacteria isolated from infant feces. Probiotics Antimicrob. 2021, 13, 90-101.

35. Werner G., Coque T. M., Franz C. M., Grohmann E., Hegstad K., Jensen L., Schaik W., Weaver K.: Antibiotic resistant enterococci-tales of a drug resistance gene trafficker. Int. J. Med. Microbiol. 2013, 303, 360-379.

36. Yang Z., Suomalainen T., Mayra-Makinen A., Huttenen E.: Antimicrobial activity of 2-pyrrolidone-5-carboxylic acid produced by lactic acid bacteria. J. Food Prot. 1997, 60, 786-790.

37. Yu H. S., Lee N. K., Jeon H. L., Eom S. J., Yoo M. Y., Lim S. D., Paik H. D.: Benzoic acid production with respect to starter culture and incubation temperature during yogurt fermentation using response surface methodology. Korean J. Food Sci. Anim. Resour. 2016, 36, 427.

38. Zanichelli D., Baker T. A., Clifford M. N., Adams M. R.: Inhibition of Staphylococcus aureus by oleuropein is mediated by hydrogen peroxide. J. Food Prot. 2005, 68, 1492-1496.

Corresponding author: Nazlı Kanca, PhD, Department of Dairy Technology, Faculty of Agriculture, Ankara University, 06110, Diskapi, Ankara, Turkey; e-mail: nazli.turkmen@ankara.edu.tr 